\title{
Netrin1-DCC-Mediated Attraction Guides Post-Crossing Commissural Axons in the Hindbrain
}

\author{
Farnaz Shoja-Taheri, ${ }^{1,2}$ Arielle DeMarco, ${ }^{1}$ and Grant S. Mastick ${ }^{1}$ \\ ${ }^{1}$ Department of Biology, University of Nevada, Reno, Nevada 89557, and ${ }^{2}$ Department of Cell Biology and Human Anatomy, University of California, Davis \\ School of Medicine, Davis, California 95616
}

Commissural axons grow along precise trajectories that are guided by several cues secreted from the ventral midline. After initial attraction to the floor plate using Netrin 1 activation of its main attractive receptor, DCC (deleted in colorectal cancer), axons cross the ventral midline, and many turn to grow longitudinally on the contralateral side. After crossing the midline, axons are thought to lose their responsiveness to Netrin 1 and become sensitive to midline Slit-Robo repulsion. We aimed to address the in vivo significance of Netrin1 in guiding post-crossing axon trajectories in mouse embryos. Surprisingly, in contrast to the spinal cord, Netrin1 and DCC mutants had abundant commissural axons crossing in the hindbrain. In Netrin1 and DCC mutants, many post-crossing axons made normal turns to grow longitudinally, but projected abnormally at angles away from the midline. In addition, exposure of cultured hindbrain explants to ectopic Netrin 1 caused attractive deflection of post-crossing axons. Thus, Netrin1-DCC signaling is not required to attract pre-crossing axons toward the hindbrain floor plate, but is active in post-crossing guidance. Also in contrast with spinal cord, analysis of hindbrain post-crossing axons in Robo1/2 mutant embryos showed that Slit-Robo repulsive signaling was not required for post-crossing trajectories. Our findings show that Netrin1-DCC attractive signaling, but not Slit-Robo repulsive signaling, remains active in hindbrain postcrossing commissural axons to guide longitudinal trajectories, suggesting surprising regional diversity in commissural axon guidance mechanisms.

Key words: axon guidance; commissural axon; DCC; Netrin; Robo; Slit

\section{Significance Statement}

The left and right sides of the brainstem and spinal cord are connected primarily by axon fibers that grow across the ventral midline, and then away on the other side to their targets. Based on spinal cord, axons are initially attracted by diffusible attractive protein signals to approach and cross the midline, and then are thought to switch to repulsive cues to grow away on the opposite side. Our results in the hindbrain show that the major midline attractant, Netrin1, is not required for midline crossing. However, the post-crossing axons depend on Netrinl attraction to set their proper trajectories on the other side. Overall, these findings suggest that commissural axons use distinct mechanisms to navigate in different CNS regions.

\section{Introduction}

Commissural axons coordinate the two sides of the nervous system. In vertebrate embryos, commissural neuron cell bodies project their axons toward the ventral midline, which consists of floor plate cells. Once commissural axons cross, they never recross the midline, but many subpopulations turn longitudinally, either anteriorly or pos-

\footnotetext{
Received Feb. 13, 2015; revised July 14, 2015; accepted July 20, 2015.

Author contributions:F.S.-T. and G.S.M. designed research; F.S.-T. and A.D. performed research; F.S.-T., A.D., and G.S.M. analyzed data; F.S.-T. and G.S.M. wrote the paper.

This work was supported by NIH Grants HD38069, NS054740, and NS077169 to G.S.M., with further support for core facilities provided by NIH COBREs 1 P20 RR024210 and 1 P20 GM103650, and the Nevada INBRE 8 P20 GM103440-11. Netrin $1^{-1-}$, DCC ${ }^{-1-}$, and the Robo1 and 2 mutants were a gift from Marc Tessier-Lavigne (Stanford; Genentech) and Fred Charron (Institut de Recherches Cliniques de Montréal). We thank Tom Kidd for helpful comments on the paper; several people in the Mastick laboratory provided technical assistance with genotyping and other experiments, including Chris Kurnik and Hannah Jordan; Minkyung Kim for help and advice with explant assays; and Brielle Bjorke for helpful discussions.
}

teriorly, and maintain a precise pathway parallel to the midline. For these steps in navigation, the floor plate acts as a critical intermediate target that controls the direction of growth in each segment (Colamarino and Tessier-Lavigne, 1995; Tessier-Lavigne and Goodman, 1996; Kaprielian et al., 2001).

The molecular mechanisms that guide commissural axons are most intensely studied in the spinal cord. Commissural axons first grow toward the ventral midline by responding to floor platederived chemoattractants. These include Netrin1, Shh (Sonic hedgehog), and VEGF (vascular endothelial growth factor; Kennedy et al., 
1994; Serafini et al., 1994, 1996; Charron et al., 2003; Bourikas et al., 2005; Ruiz de Almodovar et al., 2011). The respective receptors for these cues, DCC (deleted in colorectal cancer; for Netrin1), Boc (for Shh), and Flk1 (for VEGF) are expressed on commissural axons (Keino-Masu et al., 1996; Fazeli et al., 1997; Okada et al., 2006; Ruiz de Almodovar et al., 2011). Neogenin also collaborates as an attractive Netrin1 receptor with DCC (Xu et al., 2014). However, upon crossing, commissural axons are thought to switch responses to repellents from the floor plate, such as the Slits, Ephrins, and Semaphorins (Stein and Tessier-Lavigne, 2001; Kullander and Klein, 2002; Plump et al., 2002; Long et al., 2004; Sabatier et al., 2004; Jevince et al., 2006; Kadison et al., 2006; Killeen and Sybingco, 2008). A number of molecules that act on multiple levels in midline switching mechanisms have been identified (Parra and Zou, 2010; Charoy et al., 2012; Philipp et al., 2012; Yam et al., 2012). Overall, these represent mechanisms for axons to prevent confusion and make appropriate responses to such a large number of potentially conflicting cues by selectively responding to only a few guidance cues at a time.

How commissural axons switch responses from attraction to repulsion has been proposed to involve silencing interactions between Netrin1 and Slit receptors (Shirasaki et al., 1998; Stein and Tessier-Lavigne, 2001). In this model, mainly based on in vitro studies on dissociated neurites in culture, upon axons crossing the midline, Netrin1-DCC attraction is suppressed by a Slittriggered interaction of the cytoplasmic domains of DCC and Robo receptors (Stein and Tessier-Lavigne, 2001). This allows commissural axons to ignore Netrin1-DCC attraction, acquire sensitivity to Slit-Robo repulsion, and to make their exit from the floor plate and to effectively move away from the floor plate to assume contralateral trajectories. Evidence for Slit-Robo silencing of Netrin1-DCC attraction was suggested by studies in a subset of mouse hindbrain neurons (Causeret et al., 2002), in zebrafish forebrain commissural axons (Zhang et al., 2012), and in mouse motor axons (Bai et al., 2011). However, the role of silencing in vivo for exiting the floor plate, or for the relative importance of Netrin1-DCC and Slit-Robo signaling in the subsequent trajectories of post-crossing axons as they grow into the contralateral tissue remains largely unknown. In fact, genetic experiments in Drosophila failed to find evidence for Slit silencing of the DCC homolog Frazzled (Garbe and Bashaw, 2007). In Caenorhabditis elegans, circumferential axon trajectories depend on synergistic responses to both Slit and Netrin (Hedgecock et al., 1990; Hao et al., 2001; Quinn et al., 2006; Killeen and Sybingco, 2008). Intriguingly, other vertebrate axon types have diverse Slit/ Netrin responses, including using Slit signals to activate Netrin responses (Bielle et al., 2011), or even Netrin to suppress Slit responses (Fothergill et al., 2014).

To learn more about the in vivo navigation of commissural axons and their post-crossing longitudinal trajectories, we performed a variety of in vivo genetic and in vitro explant strategies to test whether Netrin1-DCC signaling plays any roles in the post-crossing guidance of commissural axons. Our results reveal differences in axon responses between hindbrain and spinal cord axons. Hindbrain postcrossing commissural axons use Netrin1-DCC attractive signaling, but not Slit-Robo repulsion, suggesting continuing functions for Netrin1-DCC in post-crossing axon trajectories.

\section{Materials and Methods}

Mouse embryos. Wild-type CD1 mice were purchased from Charles River Laboratories. Mouse experiments were approved by the University of $\mathrm{Ne}-$ vada Reno IACUC and were in accordance with NIH guidelines. Netrin1, DCC, and the Robol and 2 mutants were a gift from Marc Tessier-Lavigne
(Stanford; Genentech) and Fred Charron (Institut de Recherches Cliniques de Montréal). The heterozygous strains were maintained by out crossing to a CD1 background. Embryos (of either sex) were collected at embryonic day (E) 12.5, using the convention of the morning of the vaginal plug starting at $0.5 \mathrm{~d}$ of development. PCR genotyping was performed as previously described (Serafini et al., 1996; Fazeli et al., 1997; Grieshammer et al., 2004; Long et al., 2004; Sabatier et al., 2004).

In situ hybridization. Whole mount in situ hybridization was performed using standard procedures (Mastick et al., 1997). Probe for Netrin 1 was provided by M. Tessier-Lavigne (Rockefeller University, New York, NY).

Immunohistochemistry. For whole-mount immunolabeling, neural tubes were dissected out and fixed in $4 \%$ PFA overnight. The tissues were washed in PBS containing 10\% FBS and 1\% Triton for several hours (PBST). Primary antibody (1:1000 rabbit anti- $\beta$ III tubulin; Covance) in PBST was incubated with the tissues for 3-4 d. After washing the tissues for several hours, secondary antibody (1:200 AlexaFluor 488 Donkey anti-rabbit; Invitrogen) in PBST was incubated with the tissue for 2-3 d. The tissues were washed again and mounted on the slides for further analysis. For cryostat section immunolabeling, after fixing the tissues, the embryos were embedded in $7.5 \%$ gelatin; $15 \%$ sucrose in $0.1 \mathrm{~m}$ phosphate buffer. The frozen embryo blocks were then sectioned at $20 \mu \mathrm{m}$ using a cryostat (Leica). Gelatin was melted off of the sections by incubating the slides in warm $\left(37-45^{\circ} \mathrm{C}\right) 0.1 \mathrm{~m}$ phosphate buffer for $\sim 2 \mathrm{~min}$. Sections were blocked for 30 min to $1 \mathrm{~h}$ in PBST (PBS containing 10\% FBS and $0.1 \%$ Triton X-100). After applying primary antibodies (1:1000 rabbit anti- $\beta$ III tubulin; Covance), 1:200 goat anti-DCC (Santa Cruz Biotechnology) in PBST (PBST without FBS for DCC) on the sections, slides were incubated in a humidifying chamber for $4 \mathrm{~h}$ to overnight. After washing the slides for $30 \mathrm{~min}$ in PBST, secondary antibodies (1:200 AlexaFluor 488 donkey anti-rabbit (Invitrogen), 1:200 Cy3 donkey anti goat (Jackson ImmunoResearch) were incubated with the sections for 2-4 h. After several washes in PBST, slides were mounted in FluorSave Reagent (Millipore; Calbiochem) and examined under the fluorescence microscope (Leica).

diI labeling. To label the post-crossing axon trajectories, the mesenchyme layers were dissected from the neural tube of E12.5 embryos, and the embryos were fixed in 4\% PFA overnight. The approximate boundary of the alar and basal plates, ventral to the exit point of the trigeminal nerve in rhombomere 2, was chosen as a landmark for consistent labeling of commissural axons in the hindbrain. Crystals of lipophilic fluorescent axon tracer diI were inserted superficially in the tissue using a fine tungsten needle under a dissecting microscope (Mastick and Easter, 1996). The embryos were incubated in $4 \% \mathrm{PFA}$ at $37^{\circ \mathrm{C}}$ for $1-2 \mathrm{~d}$ to let the dye to diffuse. The tissues were then mounted in FluorSave Reagent (Millipore) for imaging under a confocal microscope (Olympus FV10-ASW). To label spinal cord commissural axons, the same procedure was followed by placing diI crystal in the brachial spinal cord of E12.5 embryos. In most cases, wild-type and mutant littermates were used to compare identical stages.

Explant assay. To study the behavior of axons after midline crossing, E12.5 mouse hindbrain neural tubes were dissected out as an open book preparation. The tissues were cultured in a three-dimensional collagen gel matrix at $37^{\circ} \mathrm{C}$ incubator (Zou et al., 2000), followed by placing mock and Netrin1-transfected Cos-7 cell aggregates next to rhombomere 2 (r2) on one side of the cultures (see Fig. $4 C$ ). The cultured tissues were fixed in $4 \%$ PFA after 24 h incubation. Cos-7 cells were transfected with a Netrin 1 DNA construct using Lipofectamine 2000 (Invitrogen). The pGNETmyc chick Netrin 1 construct was a gift from $M$. Tessier-Lavigne.

To study the effect of Netrin1 on number and length of post-crossing axons, small strip of Hamburger Hamilton (HH) stage 24-26 chicken hindbrain tissues ( 1 rhombomere per strip) were bisected in the middle of the floor plate. Bisected cultures with floor plate were then cultured with 500 $\mathrm{ng} / \mathrm{ml}$ recombinant Netrin 1 protein (R\&D Systems) at $37^{\circ} \mathrm{C}$. After $30 \mathrm{~h}$ incubation, the tissues were fixed in 4\% PFA and prepared for immunolabeling and image acquisition under the fluorescence microscope (Leica).

Quantification of hindbrain and spinal cord ventral commissure thickness. Five different sections from forelimb level of spinal cord and $\mathrm{r} 2$ level of hindbrain per each embryo were used for the quantification of ventral commissure thickness. Because of the slight varying size of the embryos, 

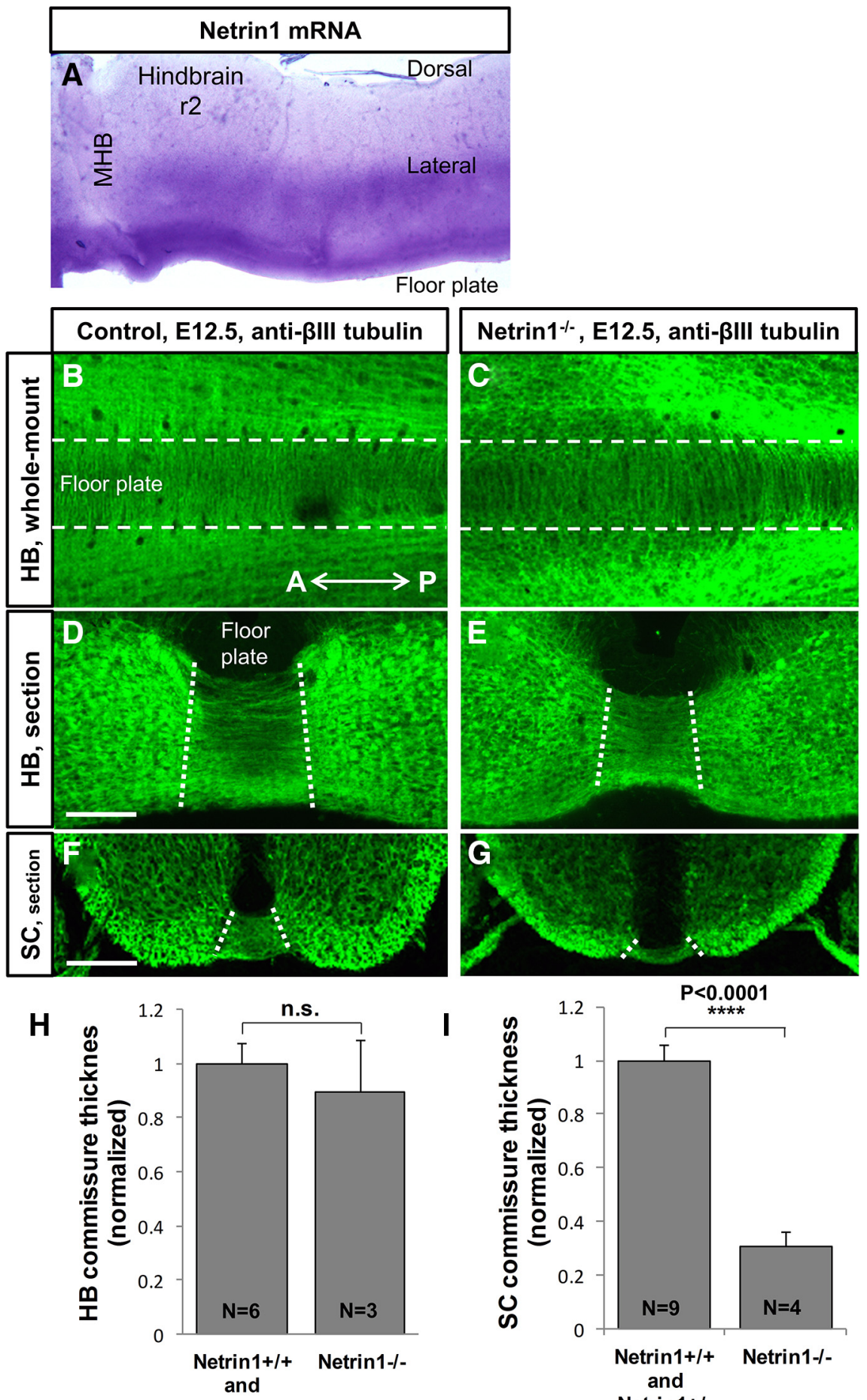

Netrin1+/-

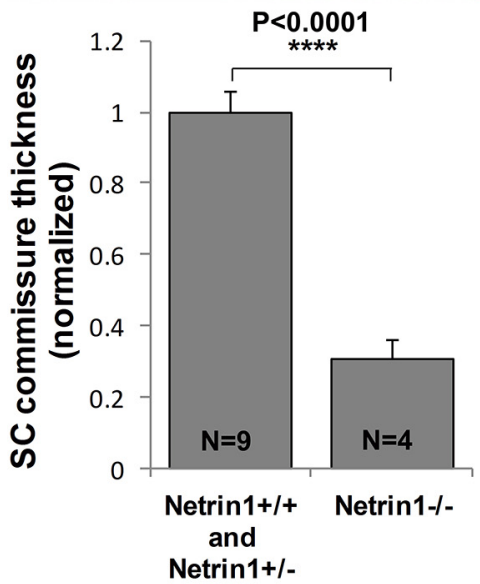

Figure 1. Netrin1 mutants have abundant commissural axons crossing the midline in the hindbrain. $\boldsymbol{A}$, Netrin1 expression pattern revealed by in situ hybridization in E10.5 mouse embryos. Floor plate and lateral expression of Netrin $1 \mathrm{mRNA}$ is detected in the hindbrain whole-mount tissues. $\boldsymbol{B}-\boldsymbol{E}$, To show midline crossing axons, whole-mount and sections of mouse embryos were labeled with neuron-specific $\beta$ III-tubulin antibody. B, C, Hindbrain whole-mount preparations of E12.5 control (Netrin $1^{+/+}$ Netrin $1^{+/-}$) and Netrin $1^{-/-}$mutant embryos. White dashed lines represent the borderlines of the floor plate. Abundant commissural axons crossed the midline in both control (B) and Netrin $1^{-1-}$ mutant $(\boldsymbol{C})$ embryos. $\boldsymbol{D}-\boldsymbol{G}$, Transverse sections of E12.5 at $\mathrm{r} 2$ of hindbrain and brachial level of spinal cord. Hindbrain commissures were strongly formed in Netrin $1^{-/-}$mutants $(\boldsymbol{E})$ and did not show a significant decrement compared with controls $(\boldsymbol{D}) . \boldsymbol{H}, \boldsymbol{I}$, Quantification of commissures in Netrin 1 mutant hindbrain and spinal cord. The thickness of ventral commissure was quantified by measuring the distance between the pial-ventricular boundaries of each commissural bundle, which was then normalized in the spinal cord by the distance between the floor plate and roof plate, and normalized in the hindbrain by the thickness of the neural tube located next to the floor plate. Then, both hindbrain and spinal cord control values were set to 1, to enable comparison between the two regions. Graphs show that hindbrain ventral commissures in Netrin1 mutants were not significantly thinner than in controls (normalized thickness: $\mathrm{Net}^{+/+} / \mathrm{Net}^{+/-}, 1 \pm$ $0.08, n=6$ embryos; Net $^{-1-}, 0.89 \pm 0.19, n=3$ embryos; $p=0.53$ ). The spinal cord ventral commissure was significantly the values of the spinal cord were normalized by the distance between the floor plate and roof plate using Image $(\mathrm{NIH})$. To normalize the hindbrain values, the amounts were normalized by the thickness of the wall of the neural tube located next to the floor plate in each section. This normalization also facilitates comparison of hindbrain and spinal cord commissure thicknesses, because hindbrain commissures were generally thicker. The normalized thickness for each embryo was then used to perform statistical analysis by ANOVA. Student's $t$ test was used to analyze the differences between two groups. Data between the groups were considered significantly different when $p<0.05$.

Quantification of end angle trajectories of $r 2$ commissural axons. The end angle of each postcrossing axon was measured in diI labeled embryos. The direction of $\leq 25$ axons per E12.5 embryo was measured relative to the midline using ImageJ. Straight axons in control embryos were probably under-counted due to fasciculated bundles. Data are expressed as mean \pm SEM. Datasets were tested for significance using one-way ANOVA and two-tailed student's $t$ test. Data are considered significantly different from the control values when $p<0.05$.

Quantification of the post-crossing axonal trajectory and growth in explants. DiI-labeled explant tissues were used to quantify the behavior of post-crossing axons in the explants with cell aggregates. The number of explants showing any type of disruption in the post-crossing axonal trajectory as well as the number of deviated axons per explant were quantified ( $N$ is indicated under each figure). To quantify the length of post-crossing axons in control and experimental groups, the average length of $\sim 20$ longest axons in each cultured tissue was quantified using ImageJ.

\section{Results}

To study hindbrain post-crossing commissural axons in mouse embryos, we chose commissural neurons residing in r2. $\mathrm{r} 2$ was chosen because the trigeminal cranial nerve makes this rhombomere a good landmark for consistent labeling. In $\mathrm{r} 2$, the subpopulation of commissural axons turns anteriorly after crossing the midline. The post-crossing longitudinal trajectories form distinct ventral and dorsal bundles. We mainly focused on the ventral post-crossing bundle because it

thinner in Netrin $1^{-1-}(\boldsymbol{G})$, compared with controls $(\boldsymbol{F}$; normalized thickness: $\mathrm{Net}^{+/+} / \mathrm{Net}^{+/-}, 1 \pm 0.06, n=7 \mathrm{em}$ bryos; Net ${ }^{-1-}, 0.3 \pm 0.05, n=5$ embryos; $^{* * * *} p<$ 0.0001 ). The commissure thickness was not significantly different between Netrin $1^{+/+}$and Netrin $1^{+/-}$embryos, therefore Netrin $1^{+/+}$and Netrin $1^{+/-}$were pooled as the control group. A, Anterior; $\mathrm{SC}$, spinal cord; $\mathrm{HB}$, hindbrain; $\mathrm{MHB}$, midbrain hindbrain boundary; $\mathrm{P}$, posterior; $\mathrm{r} 2$, rhombomere 2 . Scale bars, $100 \mu \mathrm{m}$ 

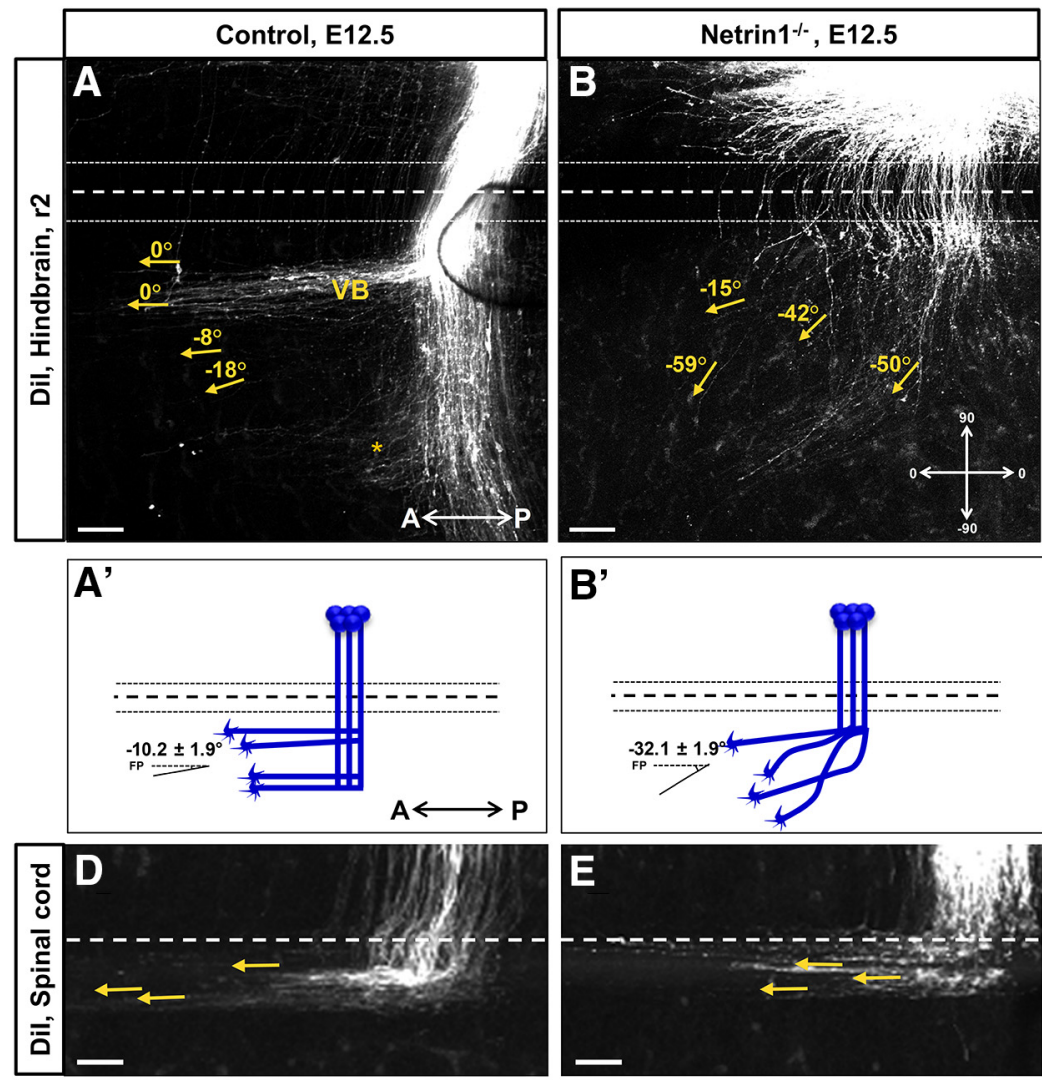

\section{B'}
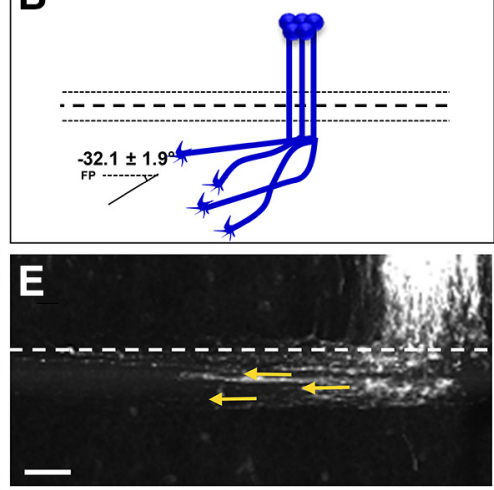

C

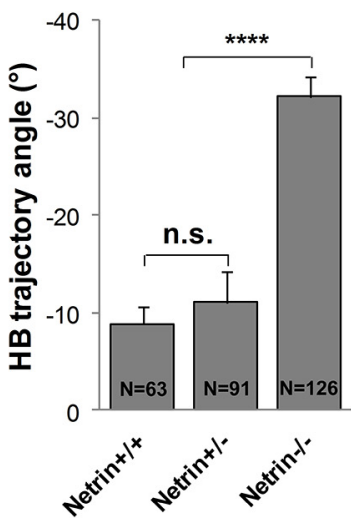

$\mathbf{F}$

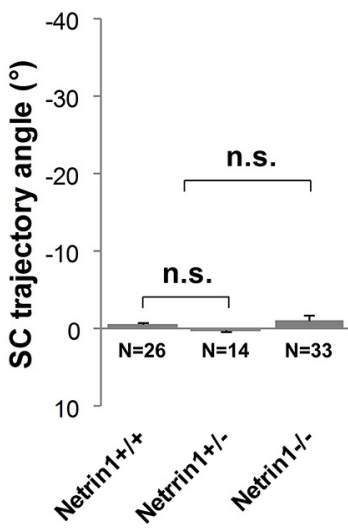

Figure 2. Netrin1 is required for post-crossing longitudinal axon guidance in the hindbrain. $\boldsymbol{A}, \boldsymbol{B}$, To trace post-crossing axonal trajectories, hindbrain open-book preparations of E12.5 control

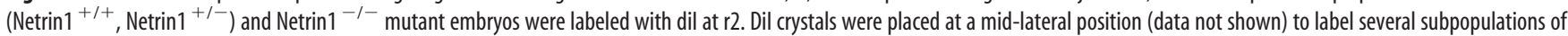
commissural axons. In control embryos, ventral bundles (VBs) of post-crossing axons turned anteriorly to grow almost parallel to the midline $(\boldsymbol{A})$. $\mathrm{A}$ bundle that turned at a dorsal position $\left({ }^{*}\right)$ and other axons that continued dorsally were also observed, but not further analyzed. In Netrin $1^{-1-}$ mutant embryos, many post-crossing axons turned anteriorly but projected at greater angles away from the midline $(\boldsymbol{B}) . \boldsymbol{A}^{\prime}, \boldsymbol{B}^{\prime}$, Schematic diagrams of commissural axon trajectories, as visualized by dil labeling, showing the deviation of post-crossing axons at angles away from the midline in Netrin1 ${ }^{-1-}$ mutant embryos $\left(\boldsymbol{B}^{\prime}\right)$ compared with controls $\left(\boldsymbol{A}^{\prime}\right)$. $\boldsymbol{C}$, Summary graph shows that the end angles of post-crossing axons (yellow arrows) were significantly wider in the ventral bundle

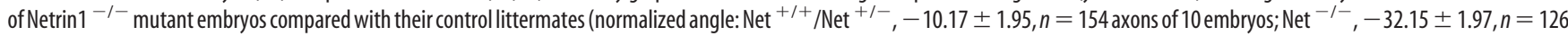
axons of 9 embryos; $\left.{ }^{* * * *} p<0.0001\right)$. To normalize the angles, they were measured relative to the midline. Quantification of the end angle did not show any significant differences between the wild-type and Netrin1 heterozygous embryos (normalized angle: Net ${ }^{+/+},-8.87 \pm 1.76, n=63$ axons of 5 embryos; Net ${ }^{+/-},-11.07 \pm 3.08, n=91$ axons of 5 embry0s; $p=0.6$ ). $\boldsymbol{D}, \boldsymbol{E}$, Spinal cord commissural axons were labeled with dil crystals in the forelimb level. These axons turned anteriorly immediately after crossing the midline and made longitudinal trajectories parallel to the midline. Quantification of the end angle of these axons did not show any significant difference between the control embryos and Netrin ${ }^{-/-}$mutants (normalized angle: Net ${ }^{+/+} /$Net ${ }^{+/-}$, $-0.375 \pm 0.2489, n=40$ axons of 5 embryos; Net ${ }^{-1-},-1.08 \pm 0.684, n=30$ axons of 5 embryos; $p=0.3 ; \boldsymbol{F}$ ). The end angles of post-crossing axons were not significantly different between Netrin $1^{+/+}$and Netrin $1^{+/-}$embryos, therefore Netrin $1^{+/+}$and Netrin $1^{+/-}$embryos together were considered as the control group. A, Anterior; $P$, posterior; ${ }^{*}$, axons at the dorsal position. Scale bars, $100 \mu \mathrm{m}$.

was more compact, and closest to the floor plate and therefore most likely to be influenced by floor plate cues.

\section{Abundant commissural axons cross the midline in the hindbrain of Netrin 1 mutants}

Netrin expression has been well characterized in the embryonic chick spinal cord, where Netrin 1 mRNA is expressed at high levels in the floor plate, with the closely related Netrin 2 mRNA at moderate levels in lateral tissues extending up to a midlateral position (Kennedy et al., 1994). Consistent with the mRNA pattern, the combined Netrin protein pattern was revealed by antibody labeling to form a ventral-high gradient, extending into midlateral tissue (Kennedy et al., 2006). Mice have a Netrin1 gene, but not Netrin2; however, the Netrin 1 mRNA and protein patterns result in a similar overall Netrin ventral-high gradient (Kennedy et al., 2006). The spinal cord Netrin gradient provides critical attractive activity for the ventral trajectories of precrossing commissural axons (Kennedy et al., 1994). In the hindbrain, Netrin 1 mRNA patterns were previously observed to be similar to the spinal cord patterns (Kennedy et al., 1994; Kim et al., 2014). For the current study, we confirmed the Netrin 1 mRNA pattern by in situ hybridization, and found Netrin1 mRNA in the hindbrain to be similar to the spinal cord patterns, with both floor plate and lateral expression (Fig. $1 A$ ). This $\mathrm{Ne}$ trin 1 hindbrain pattern of expression suggests guidance functions consistent with spinal cord.

To study the role of Netrin1 in the guidance of pioneer axons in the hindbrain, we examined mouse embryos lacking Netrin1, and were surprised to see that the hindbrain ventral commissures were relatively normal (Fig. $1 B-E$ ). To visualize commissural axons in the hindbrain and spinal cord, we first performed $\beta$ III-tubulin antibody labeling to stain hindbrain and spinal cord crossing axons at E12.5, a time when commissural axons have crossed the midline. We measured the thickness of commissural ventral bundle in cryostat sections of control and Netrin1 mutant embryos (Fig. 1D-G). Consistent with previously published studies (Serafini et al., 1996), the spinal cord ventral commissural bundle was dramatically thinner in Netrin 1 mutants compared with control embryos (Fig. 1F- 

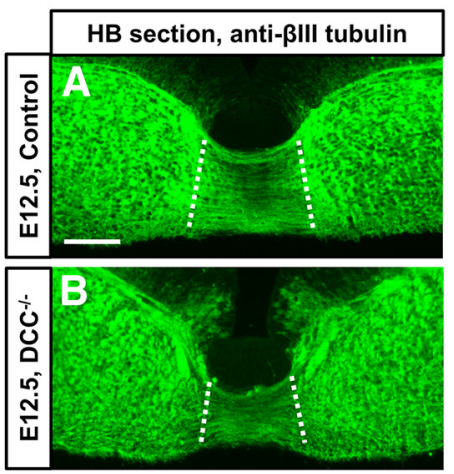

G

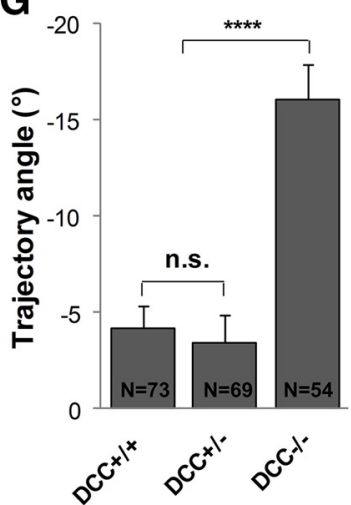

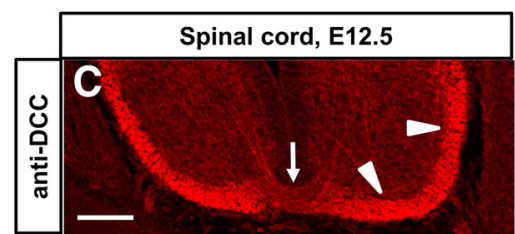
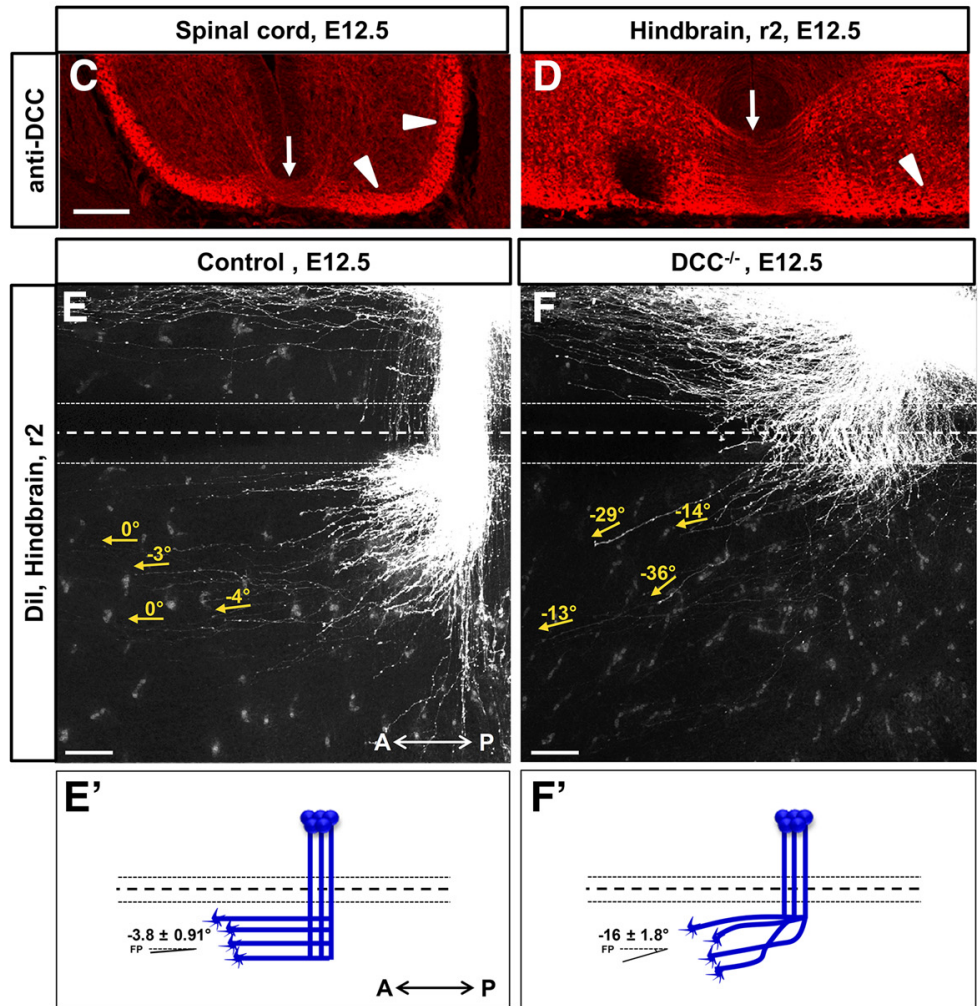

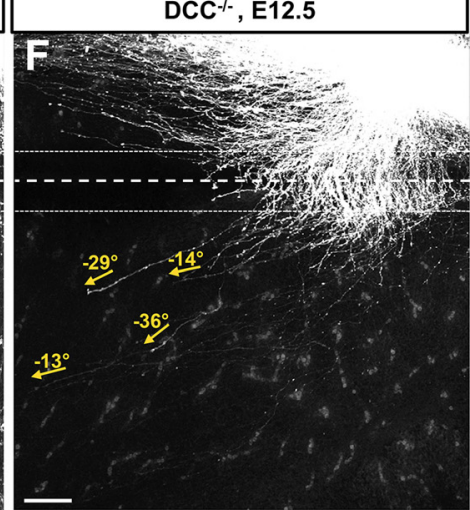

F'

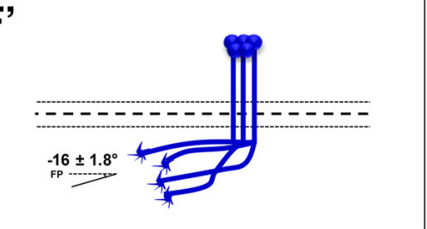

Figure 3. $D C C$ receptor is required for post-crossing longitudinal axon guidance in the hindbrain. $A, B, D C C$ mutants had abundant commissural axons crossing the midline in the hindbrain. Hindbrain commissure was strongly formed in DCC ${ }^{-1-}$ mutants $(\boldsymbol{B})$ and did not show a significant decrement compared with controls $(\boldsymbol{A})$. $\boldsymbol{C}, \boldsymbol{D}$, To determine $D C C$ expression pattern in the post-crossing axons, hindbrain and spinal cord transverse sections of E12.5 wild-type embryos were labeled with DCC antibody. DCC protein was expressed on midline crossing commissural axons (arrows), and its expression was maintained in longitudinal bundles, which include post-crossing axons (arrowheads) in both spinal cord ( $\boldsymbol{A}$ ) and hindbrain $(\boldsymbol{B})$. $\boldsymbol{E}, \boldsymbol{F}$, To trace post-crossing commissural axon trajectories, hindbrain open books of E12.5 control (wild-type and DCC ${ }^{+/-}$) and DCC ${ }^{-1-}$ embryos were labeled with dil crystals at intermediate positions of $\mathrm{r}_{2}$. Post-crossing commissural axons turned at angles away from the midline in $\mathrm{DCC}-/-(\boldsymbol{F})$ compared with controls $(\boldsymbol{E})$. Note that the length of post-crossing trajectories varied from embryo to embryo due to slightly different placements of label sites; DCC mutant labels tended to have post-crossing trajectories similar in length and angle to Netrin1 mutants (Fig. 2). $\boldsymbol{E}^{\prime}, \boldsymbol{F}^{\prime}$, Schematic drawing of the post-crossing axonal behavior showing deviation of axons at angles away from the midline in DCC ${ }^{-1-}\left(\boldsymbol{F}^{\prime}\right)$, but not in the control embryos $\left(\boldsymbol{E}^{\prime}\right)$. $\boldsymbol{G}$, Summary graph showing that the distal ends of post-crossing axons (yellow arrows) significantly diverged dorsally in DCC mutants compared with wild-type (normalized angle: $D C C^{+/+} / D C C^{+/-},-3.84 \pm 0.91, n=142$ axons of 8 embryos; DCC $-1-$, $-16.1 \pm 1.81, n=54$ axons of 4 embryos; $\left.{ }^{* * *} p<0.0001\right)$. The end angles of post-crossing axons were not significantly different between DCC ${ }^{+/+}$and DCC ${ }^{+/-}$embryos, therefore DCC $+/+$ and DCC ${ }^{+/-}$together were considered as the control group (normalized angle: $\mathrm{DCC}{ }^{+/+},-4.19 \pm 1.16, n=73$ axons of 3 embryos; DCC ${ }^{+/-},-3.46 \pm 1.42, n=69$ axons of 5 embryos; $p=$ 0.69). A, Anterior; P, posterior. Scale bars, $100 \mu \mathrm{m}$.

$G, I)$. In contrast, in the hindbrain of Netrin1 mutants, abundant commissural axons crossed the midline (Fig. 1C,E). The thickness of the hindbrain ventral commissure bundle in Netrin 1 mutants was not significantly different from in the control (Fig. $1 D-E, H)$. Note that the hindbrain floor plate in Netrin 1 mutants has also been shown to retain normal morphology and molecular specification (Kim et al., 2014).

The observation that many commissural axons cross the midline in the hindbrain of Netrin 1 mutants was surprising and very different from what is predicted by the spinal cord. Our finding suggests that a large number of hindbrain commissural axons do not require Netrin 1 signaling for proper projection toward the ventral midline, and may perhaps use other redundant midline attractants. However, the existence of crossing axons in the hindbrain of Netrin 1 mutants made it possible to study the role of Netrin 1 in the guidance of post-crossing axons.

\section{Netrin 1 is required for hindbrain post-crossing longitudinal axon guidance}

To study the role of Netrin1 in the pathfinding of post-crossing commissural axons, we examined embryos lacking Netrin 1 by diI labeling to selectively track commissural axonal trajectories. Lipophilic diI crystals were applied in r2 of E12.5 mouse embryos.
In wild-type embryos, commissural axons made sharp turns after crossing the midline and turned anteriorly. This anterior turn occurred in ventral and dorsal longitudinal bundles, suggesting two subpopulations of commissural axons at this stage in r2, likely analogues of the dorsal and ventral funiculi of the spinal cord (Kadison et al., 2006). Axons in the ventral bundle formed a distinct fasciculated bundle. Axons in the dorsal bundle were more dispersed and scattered along the ventrodorsal axis making a less fasciculated bundle (Fig. $2 A, A^{\prime}$ ). We focused on the ventral bundle for our quantifications, because these axons were closest to the floor plate, and had a more consistent turning angle in the wild-type. In Netrin 1 mutants, these axons deviated away from the midline and formed a disorganized pattern instead of their normal distinct longitudinal tract (Fig. $2 B, B^{\prime}$ ).

We also noted that pre-crossing axon trajectories were less organized in Netrin 1 mutants, forming a wider population projecting toward the floor plate, which appeared to be a combination of a subset of commissural axons that stalled or were misguided before reaching the floor plate (Fig. 2A,B). Thus, although many axons successfully crossed the hindbrain floor plate, there appear to be Netrin1-dependent aspects of precrossing axon trajectories.

To quantify the effect of Netrin 1 on the post-crossing longitudinal trajectories, the end angle of the axons was measured. The 

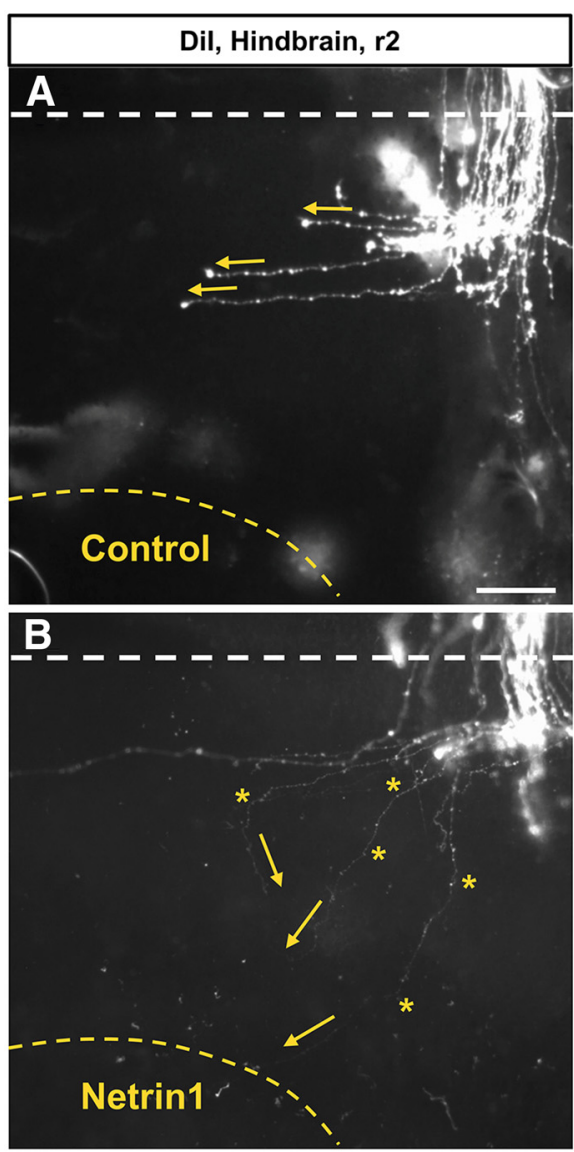

C

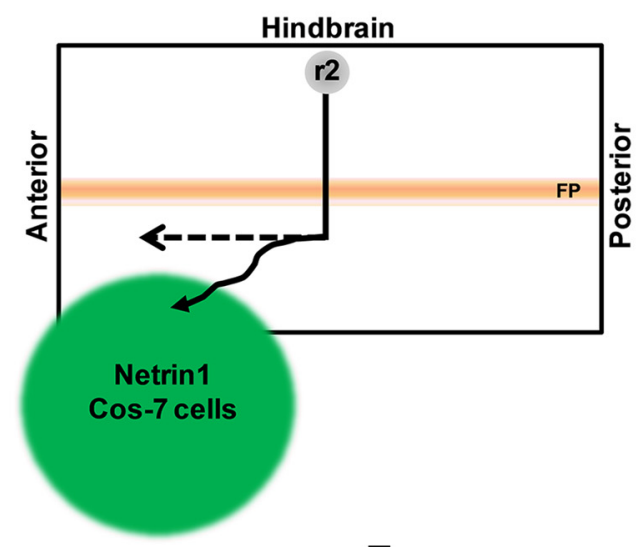

D

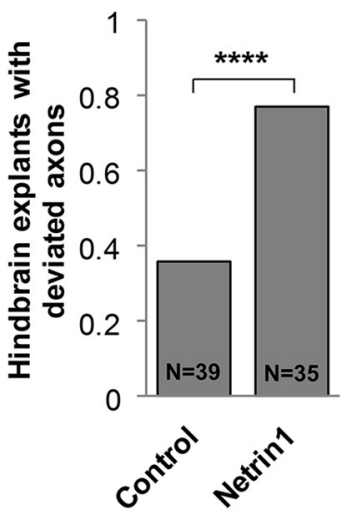

E

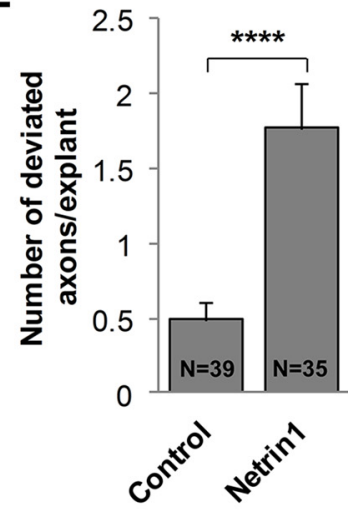

Figure 4. Netrin 1 is sufficient to attract hindbrain post-crossing commissural axons. To determine the effect of ectopic Netrin 1 on post-crossing axon guidance, hindbrain open-book preparations of 12.5 wild-type embryos were cultured in vitro with aggregates of Netrin1-transfected or mock-transfected COS cells. $\boldsymbol{A}, \boldsymbol{B}$, Hindbrain explant tissues were fixed after $24 \mathrm{~h}$ incubation, followed by labeling with dil crystals to trace the trajectory of $\mathrm{r} 2$ post-crossing axons projecting next to the mock $(\boldsymbol{A})$ and Netrin $1(\boldsymbol{B})$ expressing cells. White dashed lines represent the midline. $\boldsymbol{C}$, Schematic diagram illustrating the post-crossing trajectory of commissural axons in response to mock (dotted line) and Netrin 1 (solid arrow) expressing cells. Aggregates of Netrin 1 -expressing cells were placed lateral to the post-crossing axons. In Netrin1 explants, post-crossing axons deflected away from their longitudinal trajectories toward the Netrin1 source ( $\boldsymbol{B}$, arrows). $\boldsymbol{D}$, Graph of the proportion of explants that showed any axons with deflections away from the floor plate (i.e., angles of growth toward the ectopic Netrin 1 source). Deflections were significantly more frequent in Netrin 1 explants (almost $80 \%$ of explants had deflected axons) compared with the control group ( $\sim 35 \%$ of explants had deflected axons; Netrin $1,0.7714 \pm 0.07, n=35$ explants; control, $0.359 \pm 0.78, n=39$ explants; $\left.{ }^{* * *} p<0.0001\right)$.E, Quantification of the total number of deflected post-crossing axons within each explant. The number of axons that abnormally turned (asterisk) toward the Netrin1+ cell aggregates was also significantly higher in Netrin1 explants compared with the control experiments (Net, $1.7714 \pm 0.29 ;$ control, $0.487 \pm 0.115 ;{ }^{* * *} p<0.0001$ ). FP, Floor plate. Scale bars, $100 \mu \mathrm{m}$.

end angle was significantly larger in Netrin 1 mutants, deflecting further away from the midline, than in control littermates (Fig. $2 C)$. However, axons had normal trajectories in Netrin $1^{+/-}$ heterozygous embryos suggesting that a single wild-type Netrin 1 allele was sufficient to keep post-crossing axons in their correct pathways (Fig. 2C). Furthermore, the defasciculation of the postcrossing tracts suggest additional Netrin 1 functions in promoting fasciculation and possibly other aspects of organizing postcrossing trajectories.

For comparison, we tested the role of Netrin 1 on the postcrossing longitudinal trajectories in the spinal cord. The numbers of post-crossing axons were greatly reduced in the Netrin $1^{-1-}$ mutant spinal cord, therefore only a limited number of embryos that had a few post-crossing axons could be analyzed. These few spinal commissural axons with normal attraction toward and across the midline may originate from the ventral-most commissural interneurons in which their projection toward the ventral midline is Netrin1independent (Rabe et al., 2009). To study the effect of Netrin 1 on the guidance of post-crossing longitudinal trajectories, medial longitudinal commissural class of spinal cord commissural axons were selected (Kadison et al., 2006). These axons turn immediately after crossing the midline and take a very distinct pathway parallel to the midline (Fig. 2D,E). Although the number of crossing axons in $\mathrm{Ne}$ trin 1 mutants was reduced, measuring the end angle of these axons in Netrin 1 mutants and the control littermates showed no significant differences between these two groups (Fig. 2F).

In summary, loss of Netrin1 disrupts the proper pathfinding of post-crossing longitudinal trajectories in the hindbrain, but not in the spinal cord. These results suggest that Netrin1 plays a major role in guiding the longitudinal trajectories of post-crossing axons in the hindbrain, and therefore these axons retain their responsiveness to Netrin1. The main Netrin1 responses of hindbrain post-crossing commissural axons appear to include attracting longitudinal trajectories to be parallel to the midline, and to promote fasciculation into organized tracts.

\section{DCC receptor is required for hindbrain post-crossing longitudinal axon guidance}

Netrin1 attracts pre-crossing commissural axons toward the floor plate mainly through the DCC receptor (Keino-Masu et al., 1996), although with some attractive contributions by Neogenin 

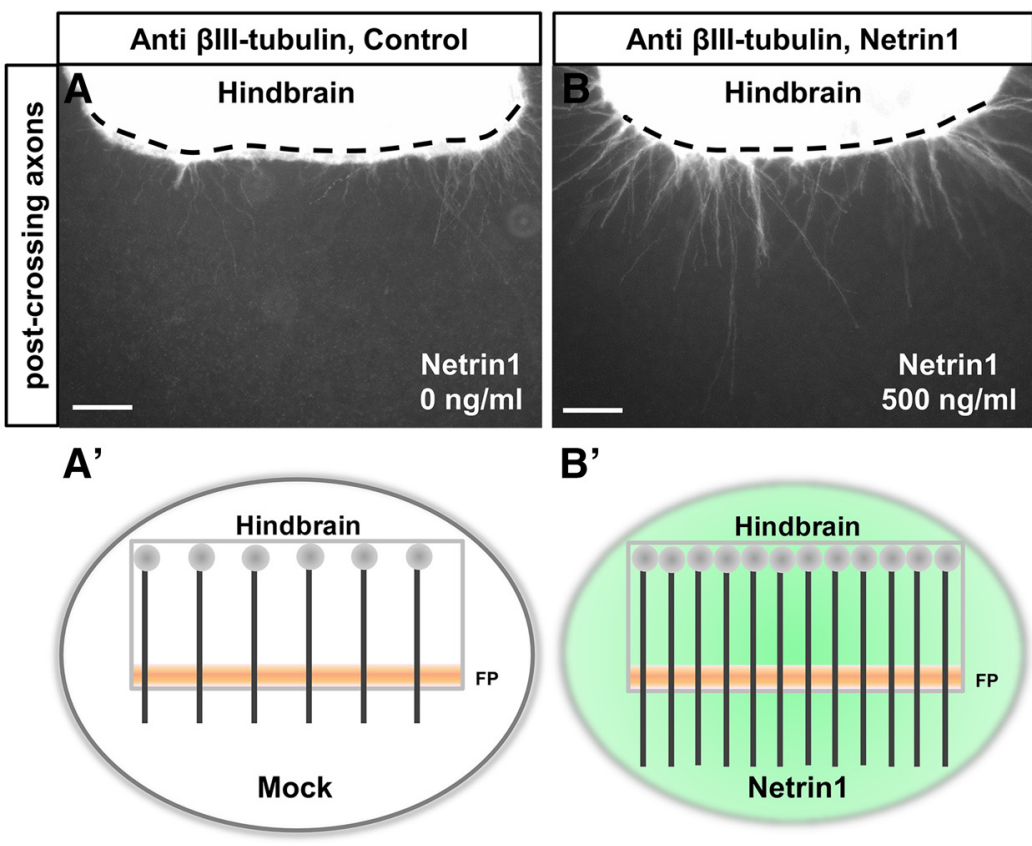

B'

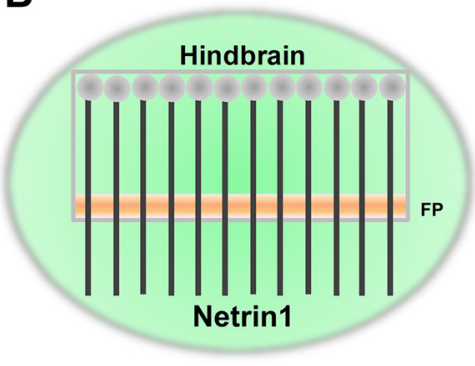

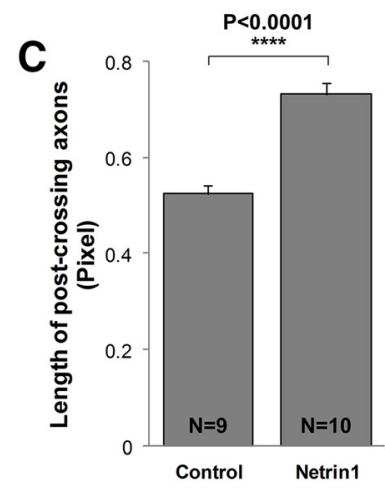

Control Netrin1

Figure 5. Netrin1 is sufficient in hindbrain explants to increase the number and length of post-crossing commissural axons. Explants of bisected hindbrain plus floor plate of HH stage $24-26$ chicken hindbrain tissues were cultured with recombinant chick Netrin 1 protein ( 0 and $500 \mathrm{ng} / \mathrm{ml}$ ) to test the effect of Netrin 1 on post-crossing axons. $\boldsymbol{A}, \boldsymbol{B}$, Embryos were stained with $\beta$ III-tubulin antibody to label post-crossing axons. Netrin 1 increases the number of post-crossing axons emerging from the explants. Control explants showed little outgrowth of post-crossing axons $(\boldsymbol{A})$, whereas explants incubated with $500 \mathrm{ng} / \mu$ l Netrin1 showed a significant increase compared with the control $(\boldsymbol{B}, \boldsymbol{C})$. White dashed lines represent the contralateral borderline of the floor plate. $\boldsymbol{A}^{\prime}, \boldsymbol{B}^{\prime}$. Schematic diagram illustrating the post-crossing outgrowth of commissural axons in the presence and absence of recombinant chicken Netrin 1 protein. $\boldsymbol{C}$, Quantification of the number of axons emerging from the hindbrain explants shows a significant increase in post-crossing axon length at higher concentrations of Netrin 1 (post-crossing: Net, $0.7313 \pm 0.02, n=10$ hindbrain tissues; Control, $0.5247 \pm 0.02, n=9$ hindbrain tissues; $\left.{ }^{* * * *} p<0.0001\right)$. FP, Floor plate. Scale bar, $100 \mu \mathrm{m}$.

(Xu et al., 2014). Here we aimed to study the role of DCC in post-crossing axon guidance and determine whether the DCC receptor, as for pre-crossing axons, guides the trajectory of postcrossing axons. Similar to Netrin $1^{-1-}$ mutants, a large number of commissural axons cross the midline in the hindbrain of DCC mutants (Fig. $3 A, B$ ). As in Netrin 1 mutants, the pre-crossing axon trajectories appeared less organized. We first verified that DCC was expressed on post-crossing axons in E12.5 embryos. DCC antibody labeling was detected on the lateral and dorsal funiculi in both hindbrain and spinal cord sections (Fig. $3 C, D$ ), consistent with post-crossing axon trajectories, although also mixed with ipsilateral longitudinal projections. To examine the function of DCC in the guidance of post-crossing axons, we examined embryos lacking DCC. We performed diI labeling on the commissural neurons of $\mathrm{r} 2$ to selectively trace commissural axons in this region. Similar to Netrin 1 mutants, post-crossing longitudinal trajectories were disrupted in DCC mutants, and axons deviated away from the midline (Fig. $3 E-F, E^{\prime}-F^{\prime}$ ). In DCC mutant embryos, post-crossing axons made significantly wider angles than in control littermates, although the effect was not as strong as in Netrin 1 mutants (Fig. $3 G ;-32.15^{\circ}$ in Netrin $1^{-1-}$ mutants vs $-16.1^{\circ}$ in $\mathrm{DCC}^{-/-}$mutants). Similar to Netrin 1 , a single wild-type DCC allele was sufficient for normal longitudinal trajectories (Fig. $3 G$ ). We also noted that the dorsal projections of post-crossing axons were reduced, suggesting potential growth-promoting functions of Netrin/DCC signaling for dorsal-projecting subpopulations. Together, our results suggest a role for DCC in guiding post-crossing longitudinal axons, consistent with mediating Netrin 1 attraction toward the midline.

\section{Netrin 1 is sufficient to cause attraction in post-crossing commissural axons}

As an alternative strategy to demonstrate that post-crossing commissural axons retain their attraction to Netrin1, we tested whether Netrin 1 could attract post-crossing trajectories in hindbrain tissue by providing an ectopic Netrin 1 source, from a dorsal position, on the opposite side of the axons from the floor plate. Aggregates of Cos-7 cells expressing full-length Netrin 1 were positioned in a dorsal position next to explants of $\mathrm{r} 2$ of early E12.5 mouse tissue. At this embryonic stage, the first post-crossing axons have already crossed the midline and have turned to begin to project longitudinally (Fig. $4 A, C$ ). The explant tissues were cultured for $24 \mathrm{~h}$ to test whether the post-crossing longitudinal tracts responded to the ectopic Netrin 1 source. We labeled postcrossing commissural axons by placing diI crystals in the side contralateral to the cell aggregates and analyzed the trajectories of post-crossing axons. A subset of axons responded to Netrin 1 aggregates by projecting away from the midline and making sharp turns toward the Netrin 1 source (Fig. 4B). Explants exhibiting this phenotype were significantly more frequent in Netrin 1 explants than the controls: Almost $80 \%$ of Netrin 1 explants had some deflected axons, in contrast to $35 \%$ of control explants (Fig. $4 D$ ). We further quantified the number of deviated axons per explant and determined that in Netrin 1 explants a significantly higher number of post-crossing axons were deflected away from the midline and projected toward the cell aggregates (Fig. 4E). Thus, Netrin 1 is sufficient to attract post-crossing axons. This suggests that the ventral-high Netrin 1 gradient provides positional guidance information to guide post-crossing longitudinal trajectories in the hindbrain. 
Netrin 1 is sufficient in hindbrain explants to increase the number and length of post-crossing commissural axons

Pre-crossing commissural axons require Netrin 1 for mediating both axonal attraction and outgrowth, and in fact Netrin 1 was originally biochemically purified using an in vitro axon outgrowth assay (Serafini et al., 1994, 1996). To show whether Netrin 1, in addition to being attractive, can influence the ability of post-crossing axons to exit and grow from explants, we cultured bisected stage 24-26 chicken hindbrain tissues, which include floor plate, in the presence of Netrin 1 recombinant protein. Post-crossing axons exhibited more consistent outgrowth in hindbrain explants from chick than mouse, in our hands. Therefore, we studied the effect of Netrin 1 recombinant protein on the outgrowth of these axons in chicken explants at $\mathrm{HH}$ stage 24-26, a time when commissural axons have crossed the midline. To quantify the outgrowth of axons in each explant, the average length of axons was measured. The length of post-crossing axons increased in the presence of Netrin 1 in the media (Fig. $5 A-C, A^{\prime}-B^{\prime}$ ), and the number of outgrowing axons also increased (data not shown). These observations suggest that Netrin 1 exposure either stimulated axons to exit the explants more efficiently, increased their growth rates into the surrounding collagen gel, or both.

\section{Robo1 and Robo2 are not required for the guidance of post- crossing axons in the hindbrain}

Studies from our laboratory and others have proposed that positioning of longitudinal axons is regulated by a balance between midline attractants and repellents (Farmer et al., 2008; Kim et al., 2011, 2014; Schweitzer et al., 2013). In part, this model is based on ipsilateral longitudinal pioneer axons, which normally form ipsilateral longitudinal tracts in the wild-type hindbrain, but strongly collapse into the midline in Slit or Robo mutant mice, and deviate dorsally in Netrin 1 or DCC mutants (Farmer et al., 2008; Kim et al., 2014). Indeed, in Slit or Robo mutant spinal cords, post-crossing commissural growth cones often fail to leave the floor plate, and in some cases cross but loop back into the floor plate, suggesting that commissural axons are expelled from the floor plate by SlitRobo repulsion (Long et al., 2004; Jaworski et al., 2010). However, strong recrossing phenotype was not reported in these mutants.

We therefore wanted to test whether Robol/2 signaling plays a role in midline crossing and the positioning of postcrossing longitudinal trajectories in the hindbrain. Commissural axon populations were labeled with diI in Robol/2 double-mutants. Similar to control embryos, axons in Robo1/2 double-mutants turned sharply after crossing the midline and made distinct longitudinal tracts with no apparent guidance errors (Fig. 6A,B). The end angle of ventral bundle axons was quantified, with no significant difference between the mutants and controls (Fig. 6C). Similar to the classic Robo phenotype in flies (Kidd et al., 1998), spinal cord post-crossing axons loop back into the midline in the absence of both Robol and Robo2 (Kidd et al., 1998; Long et al., 2004; Chen et al., 2008; Jaworski et al., 2010). In our observations, post-crossing axons projecting back into the midline formed distinct loops in these mutants (Fig. 6D, E, arrowhead). The number of postcrossing axons recrossing the floor plate relative to the total number of crossing axons indicated the small proportion of axons that made loops. Interestingly, the looping was not detected in Robo1/2 mutant hindbrain, suggesting that post- crossing axons in the hindbrain do not require Slit-Robo signals (Fig. 6G,H).

To attempt to identify whether Slit/Robo signaling was required for any aspect of commissural guidance in the hindbrain, we examined embryos with less dense labels to catch commissural crossing, including analysis of single confocal optical sections to see detailed axon trajectories. Similar to previous analyses of spinal cord, a small population of hindbrain crossing axons stalled in the floor plate (Fig. $6 E, H$, arrows). The quantification of the stalled axons revealed that approximately one-fifth of the total pre-crossing axons in both hindbrain and spinal cord stall in the floor plate of Robo1/Robo2 double-mutants (Fig. $6 F-F^{\prime}, I-I^{\prime}$ ). All together, our finding suggests that, unlike what we and others have observed in the spinal cord (Long et al., 2004; Jaworski et al., 2010), Robo1/Robo2 signaling is not required for the proper pathfinding of post-crossing axons in the hindbrain. However, axons do require Robo1/Robo2 signaling to properly leave the floor plate while crossing.

\section{Discussion}

After midline crossing and turning, commissural axons choose a distinct longitudinal pathway at precise distances relative to the midline. The mechanisms that regulate the longitudinal trajectories of post-crossing commissural axons remain unclear. These axons navigate next to the midline and therefore are in close contact to the attractive and repulsive guidance cues secreted from the floor plate. We considered in the present study whether Netrin 1, the main floor plate attractive cue, along with Slit-Robo repulsion, could potentially guide the longitudinal trajectory of post-crossing axons. Surprisingly, our in vivo finding provides evidence that postcrossing longitudinal axons in the hindbrain require Netrin 1 for their proper pathfinding. We verified our results in a complementary set of in vitro experiments showing that ectopic expression of Netrin 1 attracts post-crossing axons, and causes longer axons to exit from hindbrain explants, together suggesting that post-crossing axons retain Netrin responses.

The prior report of hindbrain explant cultures showed that post-crossing axons did not turn toward either ectopic floor plate or Netrin 1 sources (Shirasaki et al., 1998). An important caveat is that those prior experiments involved cultured rat cerebellar plate explants from $\mathrm{r} 1$, and studied the behavior of post-crossing axons that grow dorsally (straight, away from the floor plate) instead of turning longitudinally.

The specific Robo-mediated silencing mechanism was proposed based on in vitro experiments (Stein and Tessier-Lavigne, 2001), which showed that Slit2 silences Netrin1-mediated attraction in dissociated Xenopus commissural neurons. It is possible that in vitro culture conditions, or overexpression of Robos, could change the balance of receptor interactions on the surface of axons to account for their results from dissociated cultured neurons.

A number of other studies have also revealed Netrin-Slit interactions which are distinct from silencing. A recent study showed that Robo1 signaling does not silence Netrin 1 attraction in neocortical axons of the forebrain and in fact, Robol repulsion is inhibited by DCC signaling in the pre-crossing axons of these neurons (Fothergill et al., 2014). After midline crossing, DCC expression is downregulated, allowing the post-crossing axons to be repelled by Robol signaling. Furthermore, it was reported in another study that thalamocortical axons are not responsive to Netrin 1 alone, and in fact Netrin 1 attraction is dependent upon Slit signaling (Bielle et al., 2011; Dupin et al., 2015). In a third 

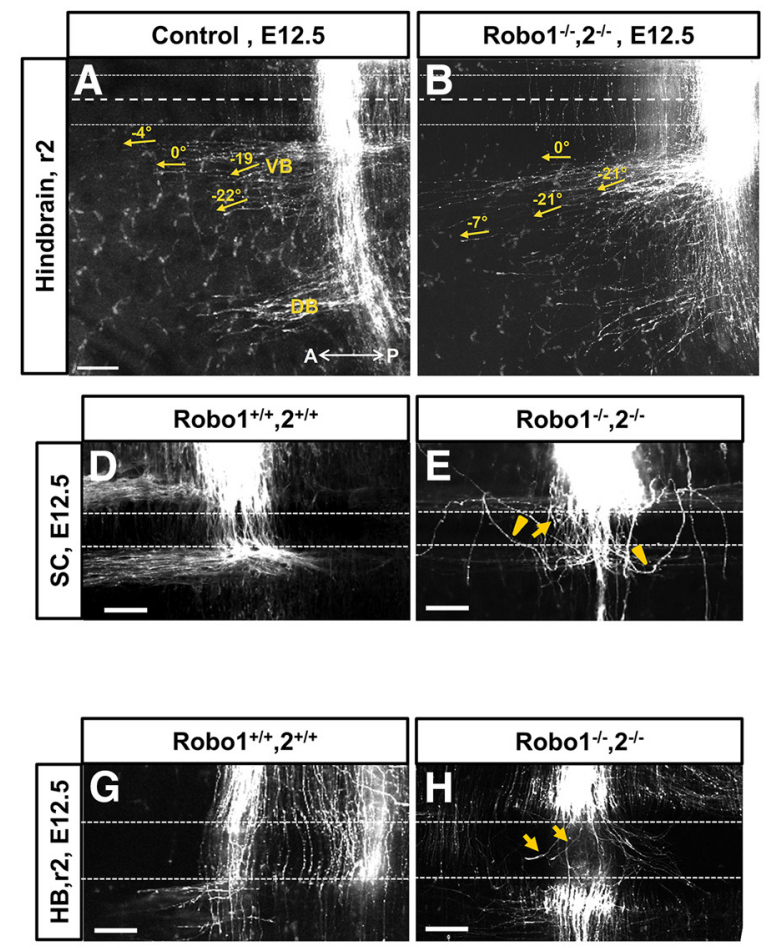

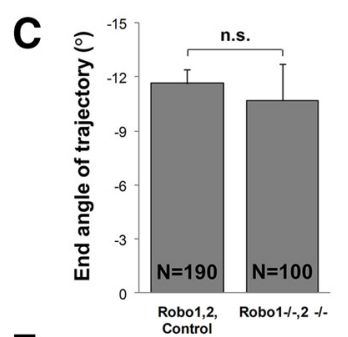

F
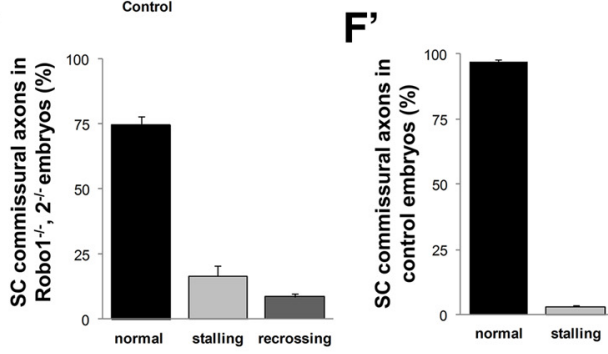

I
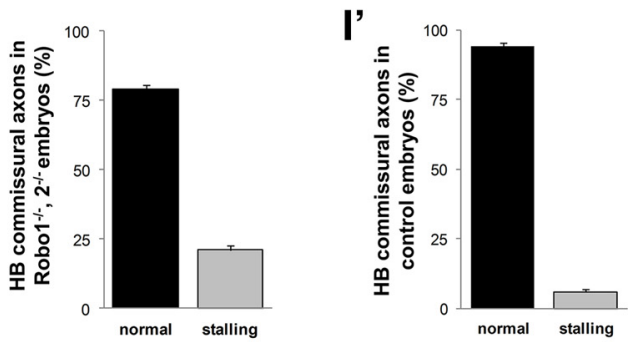

Figure 6. Robo1 and Rob02 are not required for the guidance of post-crossing longitudinal trajectories in the hindbrain. To trace post-crossing axonal trajectories, hindbrain and spinal cord open-book preparations of E12.5 wild-type (or Robo $1^{+I-}, 2^{+/-}$) and Robo $1^{-I-}, 2^{-1-}$ embryos were labeled with dil crystals. $\boldsymbol{A}, \boldsymbol{B}$, In the hindbrain of control embryos, post-crossing axons turned anteriorly to form two distinct ventral and dorsal bundles parallel to the midline $(\boldsymbol{A})$. Post-crossing axons in Robo $1^{-1-}, 2^{-I-}$ double-mutant embryos exhibited the same axon pattern. Midline crossing appeared normal, although a low level of midline stalling was noted in these mutants (B). C, Quantification of the end angle of post-crossing trajectories (yellow arrows) showed no significant differences between the control and mutant embryos (normalized angle: Robo $1^{+/+}$Robo2 ${ }^{+/+}$and Robo $1^{+/-}$Robo2 ${ }^{+/-},-11.64 \pm 0.81, n=190$ axons in 10 embryos; Robo $1^{-/-}$Robo2 ${ }^{-I-},-10.71 \pm 1.99, n=100$ axons in 5 embryos; $p=0.6 ; \boldsymbol{C}$. $\boldsymbol{D}-\boldsymbol{F}^{\prime}$. Post-crossing axons recrossed the midline in the spinal cord of Robo ${ }^{-/-}, 2^{-/-}$double-mutant embry0s $(\boldsymbol{E}$, arrowheads). In addition to recrossing, crossing axons stalled in the FP of these mutants ( $\boldsymbol{E}$, arrows). $\mathbf{G}-\boldsymbol{I}$, Hindbrain commissural axons also showed increased stalling in the floor plate of Robo $1^{-I-}, 2^{-I-}$ double-mutant embryos ( $\boldsymbol{H}$, arrows) in comparison with their control littermates $(\boldsymbol{G})$. To see trajectories in the floor plate, these embryos were labeled more sparsely than for $\boldsymbol{A}$ and $\boldsymbol{B}$. However, there were no detectable recrossing axons in the hindbrain of Robo $1^{-I-}, 2^{-I-}$ mutant embryos $(\boldsymbol{H}, \boldsymbol{I})$. $\boldsymbol{F}-\boldsymbol{F}^{\prime}, \boldsymbol{I}-\boldsymbol{I}^{\prime}$. Summary graphs showing the percentage of stalling and recrossing axons in the spinal cord and hindbrain of Robo $1^{-I-}, 2^{-I-}$ double-mutant $(\boldsymbol{F}, \boldsymbol{I})$ and control embryos $\left(\boldsymbol{F}^{\prime}, \boldsymbol{I}^{\prime}\right)$. A, Anterior; DB, dorsal bundle; $F \mathrm{P}$, floor plate; $\mathrm{P}$, posterior; $\mathrm{VB}, \mathrm{ventral}$ bundle. Scale bars, $100 \mu \mathrm{m}$.

system, through a series of single and combined mutations in the Netrin 1 and Slit pathways, it was found that pioneer longitudinal axons use a balance of Netrin 1 attraction and Slit repulsion to set the position of longitudinal trajectories (Kim et al., 2014). Together, these diverse results suggest that much remains to be learned about the interactions between these classical guidance cues.

Netrin 1 signaling predominantly regulates commissural axon attraction toward the floorplate through the DCC receptor (Keino-Masu et al., 1996; Serafini et al., 1996; Fazeli et al., 1997; Sloan et al., 2015). In post-crossing axons, we show that DCC appears to continue to mediate Netrin 1 attraction, as DCC mutants showed similar abnormal trajectories angling away from the floor plate. However, the axon angles were less severe than in Netrin 1 mutants. This suggests that Netrin 1 attraction is mediated through additional receptors, potentially Neogenin (Xu et al., 2014), or DSCAM (Down's Syndrome cell adhesion molecule; Andrews et al., 2008; Ly et al., 2008; Liu et al., 2009), although DSCAM is not genetically required for attraction to the floor plate (Palmesino et al., 2012).

Our main finding is that commissural axons in the hindbrain require ventral-ward Netrin 1 attraction to keep their trajectories oriented parallel to the floor plate. This Netrin 1 attraction may be balanced against repulsive signals, because in the loss of Netrin1mediated attraction, commissural axons lose their well organized longitudinal trajectory and deflect away from the ventral midline. In our proposed model, the direction of axonal projection is determined by a balance of attraction and repulsion on the axons (Fig. 7). For pre-crossing axons, Netrin1-DCC attraction (likely in conjunction with other midline attractants) predominates over repulsive signals to guide pre-crossing axons toward the midline. Commissural axons reach the midline, and while still being attracted to the floor plate Netrin1, their growth is promoted across the midline by cell adhesion molecules such as axonin-1 and NrCAM (Stoeckli et al., 1997). By the time they reach the far side, the growth cones have upregulated Robos and likely other repellent receptors. In addition to Slit-Robo signaling, the expression of other repulsive receptors is also regulated spatially during floor plate crossing of axons. The floor-plate guidance cue, NrCAM, increases the expression level of another repulsive receptor, PlexinA1. PlexinA1 is a Sema3B coreceptor, that in conjunction with Slit-Robo signaling, projects commissural axons out of the midline (Nawabi et al., 2010), and a recent study presents evidence that PlexinA1 also acts as a repulsive Slit receptor (Delloye-Bourgeois et al., 2015). It is likely that midline contact triggers changes in receptor levels, with the ultimate effect of adding repulsive responses to the continuing midline attraction of the growth cones. This represents an additive influence on the trajectories rather than a switch from attraction 

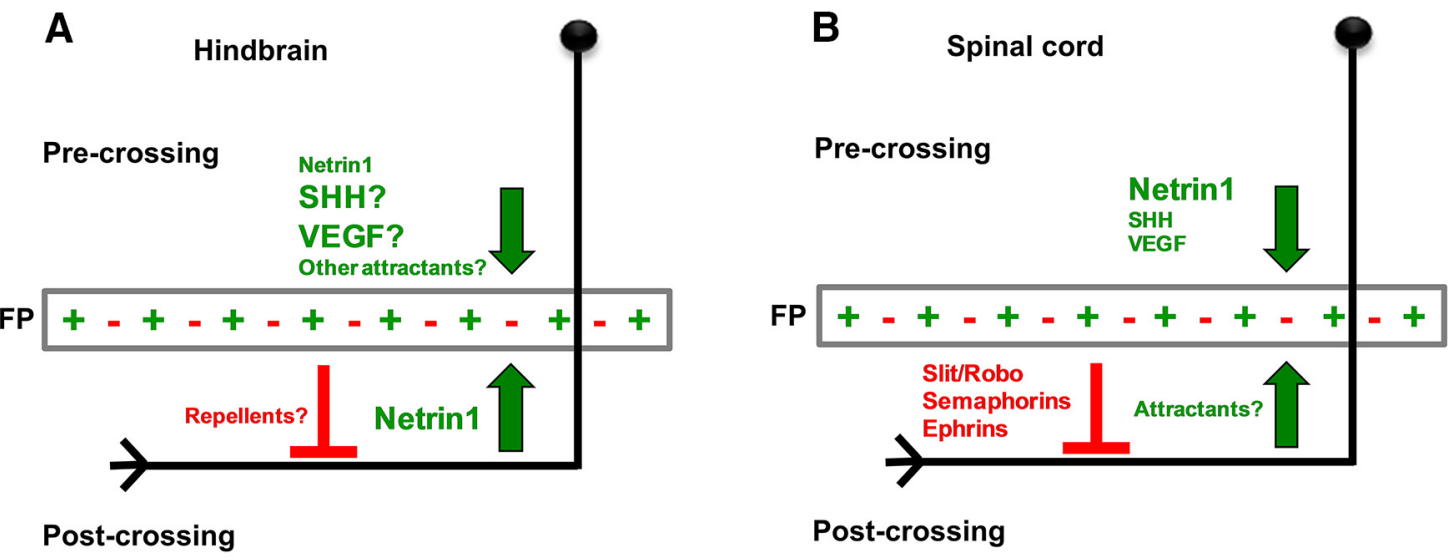

Figure 7. Molecular mechanisms regulating post-crossing longitudinal trajectories in the hindbrain and spinal cord. $A, B$, Schematic diagrams of two different proposed models regulating the proper pathfinding of growing commissural axons in the hindbrain and the spinal cord. $A$, Hindbrain pre-crossing axons: growing hindbrain commissural axons reach the midline by responding to floor plate-derived attractive cues. Netrin 1 is not predominantly required, but other floor plate-derived attractants may be more important for the attraction of pre-crossing axons toward the floor plate. Hindbrain post-crossing axons: commissural axons leave the floor plate, and turn to make longitudinal trajectories. Netrin 1 is required to attract the axons into trajectories parallel to the floor plate. This midline attraction may be balanced by unknown midline repellents, acting independently of Slit/Robo repulsion. B, Spinal cord pre-crossing axons: Netrin1-DCC signaling predominantly attracts spinal cord commissural axons toward the floor plate, with parallel but weaker attraction by SHH and VEGF. Spinal cord post-crossing axons: Slit-Robo signaling, but not Netrin1-DCC signaling, is required to guide spinal cord post-crossing longitudinal trajectories. Netrin 1 attraction may be active, but redundant to other midline attractants, or it may be silenced by activated Robo receptors.

to repulsion. After crossing the midline, these axons continue projecting dorsally away from the midline until they reach a specific turning point on the contralateral side, where the counterbalance between attractants and repellents will orient the axons into longitudinal trajectories. An implication of this model is that post-crossing trajectories could be set at different positions by variations in the attraction-repulsion balance. In addition to dorsal-ventral positioning, the anterior-posterior direction of the post-crossing trajectories would involve responses to anteroposterior cue gradients, such as Shh and Wnt (Lyuksyutova et al., 2003; Domanitskaya et al., 2010; Yam et al., 2012).

In the developing nervous system, Netrin 1 is required for commissural axon guidance and outgrowth (Kennedy et al., 1994; Serafini et al., 1994; Serafini et al., 1996). In mice lacking Netrin1, specifically at earlier embryonic stages, the spinal cord commissural axonal trajectories are disrupted, in that most of these axons are shorter and only a few of them reach and cross the floor plate. Interestingly, in contrast to spinal cord, we found that a larger number of axons reach and cross the midline in the hindbrain of Netrin 1 mutants. The more frequent crossing axons in the hindbrain than in the spinal cord can be explained in two different ways. First, specification of floor plate may be different in different regions of the neural tube. This could lead to the secretion of different types of guidance cues in the hindbrain. For example, in mouse embryos, Slit3 is expressed only in the hindbrain and spinal cord, whereas its expression is missing in the midbrain and forebrain (Farmer et al., 2008), highlighting the different structure of ventral midline at different regions. Alternatively, it is conceivable that other attractant guidance cues in the hindbrain could compensate the loss of Netrin 1 and partially rescue the observed phenotype in the spinal cord. Second, axons located in different regions may be intrinsically different. For example, due to the expression of different receptors on the surface of hindbrain and spinal cord commissural axons, these axons could respond differently to the same guidance cues. Specifically, hindbrain axons may be more responsive to hindbrain-specific attractants that could compensate for the loss of Netrin1. In contrast to the well charac- terized neuron populations in the spinal cord, the hindbrain neuronal populations remain relatively uncharacterized (for review, see Kohl et al., 2015). Together, the above examples could cause the regional differences in the guidance of hindbrain and spinal cord commissural axons.

Another difference of hindbrain axons is that they are not Robo-dependent, and travel normally in the absence of both Robo1 and Robo 2 receptors (Figs. 6B, 7A). In contrast, postcrossing commissural axons in the spinal cord remain responsive to Robo repulsion (Figs. 6E,7B). Furthermore, spinal cord postcrossing axons are not sensitive to the loss of Netrin1, meaning that Netrin 1 signaling is not necessary for the guidance of these axons. However, Netrin1-mediated attraction may be active, but redundant to other midline attractants, therefore these attractants may compensate for the loss of Netrin 1 attractive signaling (Figs. $2 F, 7 B$ ). This evidence suggests significant differences in guidance mechanisms between the spinal cord and hindbrain. It certainly remains formally possible that silencing of Netrin 1 may occur in the spinal cord commissural axons but not the hindbrain.

In summary, based on the disruption of hindbrain postcrossing longitudinal trajectories in Netrin1 and DCC mutant embryos, and the in vitro effects that Netrin 1 has on these axons, we conclude that Netrin 1 attractive signaling remains active in these axons and critical for setting their longitudinal postcrossing trajectories.

\section{References}

Andrews GL, Tanglao S, Farmer WT, Morin S, Brotman S, Berberoglu MA, Price H, Fernandez GC, Mastick GS, Charron F, Kidd T (2008) Dscam guides embryonic axons by Netrin-dependent and -independent functions. Development 135:3839-3848. CrossRef Medline

Bai G, Chivatakarn O, Bonanomi D, Lettieri K, Franco L, Xia C, Stein E, Ma L, Lewcock JW, Pfaff SL (2011) Presenilin-dependent receptor processing is required for axon guidance. Cell 144:106-118. CrossRef Medline

Bielle F, Marcos-Mondéjar P, Leyva-Díaz E, Lokmane L, Mire E, Mailhes C, Keita M, García N, Tessier-Lavigne M, Garel S, López-Bendito G (2011) Emergent growth cone responses to combinations of Slit 1 and Netrin 1 in thalamocortical axon topography. Curr Biol 21:1748-1755. CrossRef Medline

Bourikas D, Pekarik V, Baeriswyl T, Grunditz A, Sadhu R, Nardó M, Stoeckli 
ET (2005) Sonic hedgehog guides commissural axons along the longitudinal axis of the spinal cord. Nat Neurosci 8:297-304. CrossRef Medline

Causeret F, Danne F, Ezan F, Sotelo C, Bloch-Gallego E (2002) Slit antagonizes netrin-1 attractive effects during the migration of inferior olivary neurons. Dev Biol 246:429-440. CrossRef Medline

Charoy C, Nawabi H, Reynaud F, Derrington E, Bozon M, Wright K, Falk J, Helmbacher F, Kindbeiter K, Castellani V (2012) gdnf Activates midline repulsion by Semaphorin3B via NCAM during commissural axon guidance. Neuron 75:1051-1066. CrossRef Medline

Charron F, Stein E, Jeong J, McMahon AP, Tessier-Lavigne M (2003) The morphogen sonic hedgehog is an axonal chemoattractant that collaborates with netrin-1 in midline axon guidance. Cell 113:11-23. CrossRef Medline

Chen Z, Gore BB, Long H, Ma L, Tessier-Lavigne M (2008) Alternative splicing of the Robo3 axon guidance receptor governs the midline switch from attraction to repulsion. Neuron 58:325-332. CrossRef Medline

Colamarino SA, Tessier-Lavigne M (1995) The axonal chemoattractant netrin-1 is also a chemorepellent for trochlear motor axons. Cell 81:621629. CrossRef Medline

Delloye-Bourgeois C, Jacquier A, Charoy C, Reynaud F, Nawabi H, Thoinet K, Kindbeiter K, Yoshida Y, Zagar Y, Kong Y, Jones YE, Falk J, Chédotal A, Castellani V (2015) PlexinAl is a new Slit receptor and mediates axon guidance function of Slit C-terminal fragments. Nat Neurosci 18:36-45. CrossRef Medline

Domanitskaya E, Wacker A, Mauti O, Baeriswyl T, Esteve P, Bovolenta P, Stoeckli ET (2010) Sonic hedgehog guides post-crossing commissural axons both directly and indirectly by regulating Wnt activity. J Neurosci 30:11167-11176. CrossRef Medline

Dupin I, Lokmane L, Dahan M, Garel S, Studer V (2015) Subrepellent doses of Slit1 promote Netrin-1 chemotactic responses in subsets of axons. Neural Dev 10:5. CrossRef Medline

Farmer WT, Altick AL, Nural HF, Dugan JP, Kidd T, Charron F, Mastick GS (2008) Pioneer longitudinal axons navigate using floor plate and Slit/ Robo signals. Development 135:3643-3653. CrossRef Medline

Fazeli A, Dickinson SL, Hermiston ML, Tighe RV, Steen RG, Small CG, Stoeckli ET, Keino-Masu K, Masu M, Rayburn H, Simons J, Bronson RT, Gordon JI, Tessier-Lavigne M, Weinberg RA (1997) Phenotype of mice lacking functional deleted in colorectal cancer (DCC) gene. Nature 386: 796-804. CrossRef Medline

Fothergill T, Donahoo AL, Douglass A, Zalucki O, Yuan J, Shu T, Goodhill GJ, Richards LJ (2014) Netrin-DCC signaling regulates corpus callosum formation through attraction of pioneering axons and by modulating Slit2-mediated repulsion. Cereb Cortex 24:1138-1151. CrossRef Medline

Garbe DS, Bashaw GJ (2007) Independent functions of Slit-Robo repulsion and Netrin-Frazzled attraction regulate axon crossing at the midline in Drosophila. J Neurosci 27:3584-3592. CrossRef Medline

Grieshammer U, Le Ma, Plump AS, Wang F, Tessier-Lavigne M, Martin GR (2004) SLIT2-mediated ROBO2 signaling restricts kidney induction to a single site. Dev Cell 6:709-717. CrossRef Medline

Hao JC, Yu TW, Fujisawa K, Culotti JG, Gengyo-Ando K, Mitani S, Moulder G, Barstead R, Tessier-Lavigne M, Bargmann CI (2001) C. elegans slit acts in midline, dorsal-ventral, and anterior-posterior guidance via the SAX-3/Robo receptor. Neuron 32:25-38. CrossRef Medline

Hedgecock EM, Culotti JG, Hall DH (1990) The unc-5, unc-6, and unc-40 genes guide circumferential migrations of pioneer axons and mesodermal cells on the epidermis in C. elegans. Neuron 4:61-85. CrossRef Medline

Jaworski A, Long H, Tessier-Lavigne M (2010) Collaborative and specialized functions of Robol and Robo2 in spinal commissural axon guidance. J Neurosci 30:9445-9453. CrossRef Medline

Jevince AR, Kadison SR, Pittman AJ, Chien CB, Kaprielian Z (2006) Distribution of EphB receptors and ephrin-B1 in the developing vertebrate spinal cord. J Comp Neurol 497:734-750. CrossRef Medline

Kadison SR, Mäkinen T, Klein R, Henkemeyer M, Kaprielian Z (2006) EphB receptors and ephrin-B3 regulate axon guidance at the ventral midline of the embryonic mouse spinal cord. J Neurosci 26:8909-8914. CrossRef Medline

Kaprielian Z, Runko E, Imondi R (2001) Axon guidance at the midline choice point. Dev Dyn 221:154-181. CrossRef Medline

Keino-Masu K, Masu M, Hinck L, Leonardo ED, Chan SS, Culotti JG, TessierLavigne M (1996) Deleted in colorectal cancer (DCC) encodes a netrin receptor. Cell 87:175-185. CrossRef Medline

Kennedy TE, Serafini T, de la Torre JR, Tessier-Lavigne M (1994) Netrins are diffusible chemotropic factors for commissural axons in the embryonic spinal cord. Cell 78:425-435. CrossRef Medline

Kennedy TE, Wang H, Marshall W, Tessier-Lavigne M (2006) Axon guidance by diffusible chemoattractants: a gradient of netrin protein in the developing spinal cord. J Neurosci 26:8866-8874. CrossRef Medline

Kidd T, Brose K, Mitchell KJ, Fetter RD, Tessier-Lavigne M, Goodman CS, Tear G (1998) Roundabout controls axon crossing of the CNS midline and defines a novel subfamily of evolutionarily conserved guidance receptors. Cell 92:205-215. CrossRef Medline

Killeen MT, Sybingco SS (2008) Netrin, Slit and Wnt receptors allow axons to choose the axis of migration. Dev Biol 323:143-151. CrossRef Medline

Kim M, Roesener AP, Mendonca PR, Mastick GS (2011) Robo1 and Robo2 have distinct roles in pioneer longitudinal axon guidance. Dev Biol 358: 181-188. CrossRef Medline

Kim M, Farmer WT, Bjorke B, McMahon SA, Fabre PJ, Charron F, Mastick GS (2014) Pioneer midbrain longitudinal axons navigate using a balance of Netrin attraction and Slit repulsion. Neural Dev 9:17. CrossRef Medline

Kohl A, Marquardt T, Klar A, Sela-Donenfeld D (2015) Control of axon guidance and neurotransmitter phenotype of $\mathrm{dB} 1$ hindbrain interneurons by Lim-HD code. J Neurosci 35:2596-2611. CrossRef Medline

Kullander K, Klein R (2002) Mechanisms and functions of Eph and ephrin signalling. Nat Rev Mol Cell Biol 3:475-486. CrossRef Medline

Liu G, Li W, Wang L, Kar A, Guan KL, Rao Y, Wu JY (2009) DSCAM functions as a netrin receptor in commissural axon pathfinding. Proc Natl Acad Sci U S A 106:2951-2956. CrossRef Medline

Long H, Sabatier C, Ma L, Plump A, Yuan W, Ornitz DM, Tamada A, Murakami F, Goodman CS, Tessier-Lavigne M (2004) Conserved roles for Slit and Robo proteins in midline commissural axon guidance. Neuron 42:213-223. CrossRef Medline

Ly A, Nikolaev A, Suresh G, Zheng Y, Tessier-Lavigne M, Stein E (2008) DSCAM is a netrin receptor that collaborates with DCC in mediating turning responses to netrin-1. Cell 133:1241-1254. CrossRef Medline

Lyuksyutova AI, Lu CC, Milanesio N, King LA, Guo N, Wang Y, Nathans J, Tessier-Lavigne M, Zou Y (2003) Anterior-posterior guidance of commissural axons by Wnt-frizzled signaling. Science 302:1984-1988. CrossRef Medline

Mastick GS, Easter SS Jr (1996) Initial organization of neurons and tracts in the embryonic mouse fore- and midbrain. Dev Biol 173:79-94. CrossRef Medline

Mastick GS, Davis NM, Andrew GL, Easter SS (1997) Pax-6 functions in boundary formation and axon guidance in the embryonic mouse forebrain. Development 124:1985-1997. Medline

Nawabi H, Briançon-Marjollet A, Clark C, Sanyas I, Takamatsu H, Okuno T, Kumanogoh A, Bozon M, Takeshima K, Yoshida Y, Moret F, Abouzid K, Castellani V (2010) A midline switch of receptor processing regulates commissural axon guidance in vertebrates. Genes Dev 24:396-410. CrossRef Medline

Okada A, Charron F, Morin S, Shin DS, Wong K, Fabre PJ, Tessier-Lavigne M, McConnell SK (2006) Boc is a receptor for sonic hedgehog in the guidance of commissural axons. Nature 444:369-373. CrossRef Medline

Palmesino E, Haddick PC, Tessier-Lavigne M, Kania A (2012) Genetic analysis of DSCAM's role as a Netrin-1 receptor in vertebrates. J Neurosci 32:411-416. CrossRef Medline

Parra LM, Zou Y (2010) Sonic hedgehog induces response of commissural axons to Semaphorin repulsion during midline crossing. Nat Neurosci 13:29-35. CrossRef Medline

Philipp M, Niederkofler V, Debrunner M, Alther T, Kunz B, Stoeckli ET (2012) RabGDI controls axonal midline crossing by regulating Robol surface expression. Neural Dev 7:36. CrossRef Medline

Plump AS, Erskine L, Sabatier C, Brose K, Epstein CJ, Goodman CS, Mason CA, Tessier-Lavigne M (2002) Slit1 and Slit2 cooperate to prevent premature midline crossing of retinal axons in the mouse visual system. Neuron 33:219-232. CrossRef Medline

Quinn CC, Pfeil DS, Chen E, Stovall EL, Harden MV, Gavin MK, Forrester WC, Ryder EF, Soto MC, Wadsworth WG (2006) UNC-6/netrin and SLT-1/slit guidance cues orient axon outgrowth mediated by MIG-10/ RIAM/lamellipodin. Curr Biol 16:845-853. CrossRef Medline

Rabe N, Gezelius H, Vallstedt A, Memic F, Kullander K (2009) Netrin-1dependent spinal interneuron subtypes are required for the formation of left-right alternating locomotor circuitry. J Neurosci 29:15642-15649. CrossRef Medline 
Ruiz de Almodovar C, Fabre PJ, Knevels E, Coulon C, Segura I, Haddick PC, Aerts L, Delattin N, Strasser G, Oh WJ, Lange C, Vinckier S, Haigh J, Fouquet C, Gu C, Alitalo K, Castellani V, Tessier-Lavigne M, Chedotal A, Charron F, Carmeliet P (2011) VEGF mediates commissural axon chemoattraction through its receptor Flk1. Neuron 70:966-978. CrossRef Medline

Sabatier C, Plump AS, Le Ma, Brose K, Tamada A, Murakami F, Lee EY, Tessier-Lavigne M (2004) The divergent Robo family protein rig-1/ Robo3 is a negative regulator of slit responsiveness required for midline crossing by commissural axons. Cell 117:157-169. CrossRef Medline

Schweitzer J, Löhr H, Bonkowsky JL, Hübscher K, Driever W (2013) Simla and Arnt 2 contribute to hypothalamo-spinal axon guidance by regulating Robo2 activity via a Robo3-dependent mechanism. Development 140: 93-106. CrossRef Medline

Serafini T, Kennedy TE, Galko MJ, Mirzayan C, Jessell TM, Tessier-Lavigne M (1994) The netrins define a family of axon outgrowth-promoting proteins homologous to C. elegans UNC-6. Cell 78:409-424. CrossRef Medline

Serafini T, Colamarino SA, Leonardo ED, Wang H, Beddington R, Skarnes WC, Tessier-Lavigne M (1996) Netrin-1 is required for commissural axon guidance in the developing vertebrate nervous system. Cell 87:10011014. CrossRef Medline

Shirasaki R, Katsumata R, Murakami F (1998) Change in chemoattractant responsiveness of developing axons at an intermediate target. Science 279:105-107. CrossRef Medline

Sloan TF, Qasaimeh MA, Juncker D, Yam PT, Charron F (2015) Integration of shallow gradients of Shh and Netrin-1 guides commissural axons. PLoS Biol 13:e1002119. CrossRef Medline

Stein E, Tessier-Lavigne M (2001) Hierarchical organization of guidance receptors: silencing of netrin attraction by slit through a Robo/DCC receptor complex. Science 291:1928-1938. CrossRef Medline

Stoeckli ET, Sonderegger P, Pollerberg GE, Landmesser LT (1997) Interference with axonin- 1 and NrCAM interactions unmasks a floor-plate activity inhibitory for commissural axons. Neuron 18:209-221. CrossRef Medline

Tessier-Lavigne M, Goodman CS (1996) The molecular biology of axon guidance. Science 274:1123-1133. CrossRef Medline

Xu K, Wu Z, Renier N, Antipenko A, Tzvetkova-Robev D, Xu Y, Minchenko M, Nardi-Dei V, Rajashankar KR, Himanen J, Tessier-Lavigne M, Nikolov DB (2014) Neural migration. Structures of netrin-1 bound to two receptors provide insight into its axon guidance mechanism. Science 344:1275-1279. CrossRef Medline

Yam PT, Kent CB, Morin S, Farmer WT, Alchini R, Lepelletier L, Colman DR, Tessier-Lavigne M, Fournier AE, Charron F (2012) 14-3-3 proteins regulate a cell-intrinsic switch from sonic hedgehog-mediated commissural axon attraction to repulsion after midline crossing. Neuron 76:735-749. CrossRef Medline

Zhang C, Gao J, Zhang H, Sun L, Peng G (2012) Robo2-slit and DCCnetrin1 coordinate neuron axonal pathfinding within the embryonic axon tracts. J Neurosci 32:12589-12602. CrossRef Medline

Zou Y, Stoeckli E, Chen H, Tessier-Lavigne M (2000) Squeezing axons out of the gray matter: a role for slit and semaphorin proteins from midline and ventral spinal cord. Cell 102:363-375. CrossRef Medline 